\title{
Politizar el paisaje, ilustrar la patria: nacionalismo, dictadura chilena y proyecto editorial $^{*}$
}

\section{Politicizing the Landscape, Illustrating the Nation: nationalism, Chilean Dictatorship and Publishing Projects}

\author{
Isabel Jara \\ Facultad de Filosofía y Humanidades y Facultad de Artes, Universidad de Chile, \\ Chile \\ jara.isabel@gmail.com
}

Resumen: El presente artículo explora cómo el paisaje chileno fue reinventado por la ideología nacionalista y por el Régimen Militar, a través de la Editora Nacional Gabriela Mistral mientras ésta fue del Estado (1973-1976), particularmente mediante sus ilustraciones. En el cruce analítico de la historia de las ideas políticas, de la cultura y de la iconografía, revisa cómo confluyeron demandas ideológicas y medios editoriales y visuales para «patrimonializar» políticamente el territorio. Finalmente, propone que el paisaje fue proyectado simbólicamente como base del patriotismo y como elemento «naturalizador» de una población uniformada y del orden autoritario.

Palabras clave: nacionalismo, dictadura chilena, gráfica editorial, paisaje.

Abstract: This paper explores how the Chilean landscape was reinvented by the nationalist ideology and the military regime, particularly through the illustrations published by the Editora Nacional Gabriela Mistral while it was a state publishing house (1973-1976). Within the mixed framework of the history of political thought, cultural history, and iconography, the paper looks at the way in which both ideological demands as well as visual and editorial media converged to transform the territory in a political «heritage». Finally, the paper proposes that landscape was symbolically projected as the basis of patriotism, and as a «normalizing» element of a uniformed population and of an authoritarian order.

Key words: Nationalism, Chilean dictatorship, editorial graphics, landscape.

* El presente artículo es producto del proyecto Fondecyt 11080048. Una versión preliminar se presentó en las XV Jornadas de Historia Regional de Chile. Arica, octubre de 2010. 


\section{A MODO DE INTRODUCCIÓN: IDEOLOGÍA POLÍTICA Y PAISAJE}

Es posible pensar que el Régimen Militar reinventó la identidad nacional recurriendo al ícono paisajístico tradicional ya politizado por el nacionalismo, aportando en ello la Editora Nacional Gabriela Mistral (ENGM) con una ilustración gráfica que convertía el paisaje chileno en una 〈causa política y en una guisa de $\langle\text { saber }\rangle^{1}$.

Naturalmente, ello no fue un arrebato original de aquel régimen ni de su editorial. La necesidad de los gobiernos e ideologías anteriores de inventarse una identidad general que incorporara los paisajes locales había significado una cita constante del territorio en las narrativas nacionales desde el siglo XIX. Pero la dictadura recogió la interpretación que, durante el siglo XX, había hecho el pensamiento nacionalista del paisaje chileno, a saber: inoculado con el axioma de la unidad nacional, sobreidentificado con el paisaje de la ‘zona huasa` y politizado desde fines de los años sesenta.

Es posible recorrer dichas conexiones — desde las narrativas decimonónicas a las nacionalistas y desde éstas a la narrativa autoritaria-, pero considerando primero la relación entre ideología política y paisaje. Cabe aquí recordar que el carácter proselitista, la necesidad de legitimación y la pulsión ecuménica de cambio (de aspiración supralocal) que suelen caracterizar a las ideologías políticas suponen la apropiación de identidades regionales. De manera que tanto la transformación de los discursos en regímenes políticos como la pretendida universalización de sus supuestos ideológicos (que favorezca una hegemonía cultural que los sostenga más allá de la coerción) exigen la representación selectiva y ficcionada del paisaje ${ }^{2}$.

Sin esta operación interpretativa del paisaje, aquellos discursos serían menos globalizantes y, por ende, menos efectivos ${ }^{3}$. El éxito de su cualidad representacional simbólicopolítica —esto es, de sustituir la materialidad contingente del territorio, apropiarse de y reconfigurar su significabilidad, excluir otras representaciones alternativas y otros usos políticos - está anclada a esa operación: la de "des-localizar» espacios concretos para transformarlos en signos más abstractos y abiertos a engendrar nuevos mensajes: en particular, el mensaje de la «nación〉 o la ‘patria`.

La producción, divulgación y naturalización de cualquier versión de la identidad nacional - portadora a la vez que superadora de los «patrimonios locales»- se convierte entonces en un ejercicio necesario para la configuración y mantención en el poder de un

\footnotetext{
En un sentido adaptado de la definición de Foucault, para quien corresponde a "grupos de objetos, conjunto de enunciaciones, juegos de conceptos, series de elecciones teóricas. Los elementos así formados no constituyen una ciencia, con una estructura de identidad definida; su sistema de relaciones es seguramente menos estricto [...] Son aquello a partir de lo cual se construyen proposiciones coherentes (o no), se desarrollan descripciones más o menos exactas, se efectúan verificaciones, se despliegan teorías. Forman lo previo de lo que se revelará y funcionará como un conocimiento o una ilusión [...]» (305-307).

2 Si el territorio se considera hoy como una construcción social más que como el terreno dado, en tanto «unidad espacial socialmente moldeada y vinculada a las relaciones de poder», el paisaje se entiende como la construcción del observador. Es éste quien convierte la naturaleza en tal mediante la contemplación, en función de las relaciones que establece con - y desde el lugar que ocupa en- el espacio geográfico. Así, el paisaje resulta «la dimensión cultural de la naturaleza» (Urquijo y Barrera, 230-232).

3 Esta paradoja entre parcialidad y totalidad de la ideología, Ankersmit la aplica al partido político en democracia: «precisamente por ser simplemente sparcial, precisamente por siempre necesitar (en la terminología de Derrida) un ssuplemento〉 en la forma de otros partidos, legitima mejor la noción de conjunto y la unidad del Estado, por oblicua referencia o presunción tácita de la presencia de otros partidos» (62). Traducción libre de la autora.
} 
constructo ideológico de alcance estatal. Dicha producción supone un acto de invención, del cual se olvide que lo ha sido.

\section{INVENCIÓN DE LA NACIÓN Y PAISAJE: NARRATIVAS DECIMONÓNICAS}

De acuerdo a una línea de trabajo ya clásica, la <invención` de un evento histórico consistiría en una trama explicativa del mismo, que sería innecesaria si ella fuera evidente por sí misma; a su vez, se distinguiría de la ‘creación`, propia del ámbito religioso, en tanto no supondría producir algo desde la nada, como sí lo haría aquel concepto (O’Gorman, 9-54). Así pues, la idea de invención` no supondría la inexistencia del hecho histórico que serviría de base a su interpretación, sino que desplazaría la atención hacia el efecto de verdad pretendido por ésta, el cual estaría en sutil o franco conflicto con aquel. Es decir, el verosímil de la representación sustituiría (o pretendería sustituir) la existencia del acontecimiento, lo atraparía y se convertiría en él hasta hacérsele indistinguible.

No cabe duda de que en la producción e intervención de una identidad nacional comparece la invención —en los términos anteriores - como una operación política cardinal y muchas veces fundacional. Ha sido dicho, la «invención de tradiciones» permite instituir y modelar la cohesión social de la comunidad, implantar y acreditar privilegios, instituciones o relaciones de autoridad, levantar genealogías vinculantes con el pasado e inculcar valores y actitudes (Hobsbawm y Ranger, 8-16). Por tanto, en el corazón mismo del discurso político está la representación ${ }^{4}$.

Precisamente, como ha sido documentado, el paisaje ha sido una cita constante en las narrativas de «chilenidad» inventadas desde el siglo XIX ${ }^{5}$. Ello, porque la heterogénea geografía chilena apuntalaría una ‘tradición nacional〉 complacida de su variedad y, sobre todo, orgullosa de su <unidad en la diversidad (paisajística, étnica y cultural). Todas esas narrativas compartirían, en mayor o menor medida, tal satisfacción por un territorio plagado de muchos climas, relieves y ecosistemas, especialmente por contener incluso paisajes extremos, los cuales configurarían tipos sociales diferentes pero conectados. Por otra parte, como si fuera parte de una trama dramática, esa «loca geografía» constituiría - en dichos relatos de "chilenidad»- el desafío que curtiría el carácter del pueblo chileno. A la manera de un cuerpo que sostiene y modela una idiosincrasia, la naturaleza chilena operaría como el antagonista de un héroe - la nación- que interpretaría su papel en la historia, venciéndola o sucumbiendo.

En ese eje identitario, la cohesión nacional devendría, entonces, de unidad en la diversidad, de la fusión con el paisaje a la vez que de la lucha épica contra él. Como motivo de orgullo y fuente de identidad, no sólo para los lugareños sino para todos los ciudadanos del país, el paisaje local dejaría de ser un elemento de contradicción para la identificación

$4 \quad$ En palabras de Ankersmit: «Y puesto que la representación puede ser vista como el centro de la política porque toda política presupone la auto-conciencia de la colectividad política que es paradigmáticamente ejemplificada por la representación (política) - ello puede indicar la prioridad que hay que atribuir a una aproximación estética por sobre un enfoque ético de la política» (23). Traducción libre de la autora.

5 Atendiendo este fenómeno, internacional, por cierto, se usa la metáfora visual del paisaje como «retrato de la nación", poseedor de una presencia física con un espacio (territorio político) y un tiempo (memoria histórica y social), cuyas marcas son recalcadas con monumentos o «sitios de la memoria» (Folch-Serra, 137-159). 
con el territorio nacional y participaría en la construcción de imaginarios comunicantes, ya en el papel de recurso simbólico básico, ya en el de escenario histórico o en el de espacio de proyección geopolítica o económica.

No llama la atención que, entre las diversas narrativas de nación, la vinculada al pensamiento conservador-nacionalista hiciera del paisaje (y de uno en particular) un ícono identitario. Su tradición intelectual y trayectoria política así lo disponían, facilitándole la doble operación ideológica de convertir la relación entre nacionalidad y territorio en una de dependencia mutua, por un lado, y de presentar esa dependencia como un sello de autenticidad, por otro. Su idea de una «chilenidad» surgida de la fusión de dos pueblos «guerreros», de las batallas y de los gobiernos autoritarios, tanto como su idealización de la Independencia, enraizaron el pensamiento nacionalista-conservador en la simbología "patriota» y nacionalista decimonónica ${ }^{6}$. De allí que fuera él quien retomara insistentemente las primeras alegorizaciones paisajísticas de la «chilenidad», pero purgándole sus resabios americanistas.

En efecto, como se recordará, la relación entre naturaleza e identidad había quedado instalada desde el proceso fundacional de la república. Tempranamente, entre los referentes identitarios construidos desde la Patria Vieja - antihispanidad, indígenas, guerra, religión e historia (Silva, 47-70)—, la naturaleza ocupó también un lugar central. Entre las metáforas más divulgadas sobre dicho referente, compareció la interpretación "paisajística» de los primeros símbolos patrios: los colores de la bandera ${ }^{7}$, la fauna autóctona incorporada al escudo y la glorificación en el himno nacional, repetidos generación tras generación, hicieron de la naturaleza parte del núcleo de representación de la «chilenidad». Menos recordada, pero igualmente significativa, fue la instalación en la Plaza de Armas de Santiago, en 1821, de un árbol en homenaje de la libertad ${ }^{8}$. Ya para entonces la naturaleza dejaba de ser la materialización de la idea de patria en referencialización mimética y comenzaba a ser evocada como un símbolo nacional más, por derecho propio.

Paralelamente, como correlato cultural de lo anterior, el trabajo de artistas, escritores, cartógrafos y viajeros decimonónicos — generalmente contratados por el gobierno y divulgados después sus encargos en impresos o exposiciones- también tematizó porfiadamente la relación entre naturaleza e identidad nacional. Un ejemplo clásico es el de Claudio Gay (Mizón, 64-69). En tiempos de nacionalismo, romanticismo o positivismo, ellos tematizaron esa relación en búsqueda de una peculiaridad sustancial que distinguiera a Chile del resto de la región. De hecho, desde la creación de la Academia de Pintura como institución oficial, se desarrolló como objetivo pedagógico y político de

$6 \quad$ Por ejemplo, el Movimiento Nacional Socialista (1932-1938) adoptó la bandera de la Patria Vieja como insignia, sobreponiéndole un relámpago rojo. El Partido Nacional (1966-1994) se inspiró en la escarapela tricolor, usando como símbolo un círculo de franja exterior roja, centro blanco y estrella azul de cinco puntas. Avanzada Nacional (1984-1990), formada por ex militantes de Patria y Libertad y del Movimiento de Acción Nacional (a su vez desgajado del Partido Nacional), tenía como emblema la escarapela tricolor, con la sigla del partido al centro (AN). Heredera de la emblemática nacionalista, aunque con ideas menos extremas, Renovación Nacional (1987) se identifica con una versión modernizada de una estrella de cinco puntas, en colores azul y rojo.

7 Para Camilo Henríquez, los colores interpretaban los poderes del Estado: majestad popular (amarillo), ley (blanco) y fuerza (azul). (Henríquez). En cambio, según Alemparte el azul graficaba el cielo, el blanco la cordillera de los Andes y el amarillo de los campos de trigo (Soublette, 52; Silva, 60; Pinto y Valdivia, 54). Por supuesto, el apego al territorio puede remontarse al período colonial.

8 Tomando el ejemplo de los «árboles de la libertad» de la Francia revolucionaria, todas las capitales iberoamericanas utilizaron árboles como objetos conmemorativos (Voionmaa, 352-353). 
primer orden el aprovechar el género del paisaje ${ }^{9}$, para representar y delimitar sistemáticamente el territorio, contribuyendo así, junto al género épico-histórico, a «ilustrar» e «inmortalizar» a la «Patria»" ${ }^{10}$. Por su parte la fotografía, tal vez antes incluso que la pintura, también contribuyó a la individualización del país a través del paisaje y del retrato. De hecho, su capacidad de combinar la fugacidad y la repetición e imponerlas sobre las nociones de singularidad y perduración que cimentaban la tradición pictórica le habría permitido refundar el paisaje chileno - como el americano- antes que ésta (Kay, 28-29).

En cualquier caso, más allá de las precedencias, dicha singularización cultural de la nación a partir de la construcción simbólica del paisaje fue una tarea exitosa de cara al siglo XX: entonces se llegó a considerar que aquél era una constante del arte nacional, como sostuvo el historiador del arte Antonio Romera en su Historia de la pintura chilena de 1951 (Nordenflycht, 32), y que existía algo así como un ‘paisaje chileno> por excelencia, identificado con el espacio rural del valle central. Por otro lado, el aparato estatal confirmó su estatus de emblema nacional y su versión tradicional se convirtió en un leitmotiv del pensamiento de derechas.

\section{NACIONALISMO Y PAISAJE}

Como se sabe, a partir del primer tercio del siglo XX, la vertiente militar y la nacionalista-conservadora conformaron, en un sentido general, una ideología ${ }^{11}$, al calor del proceso de sprusianización ' del Ejército, del trabajo de ensayistas e intelectuales, de un movimiento xenófobo, nacionalista y popular, extremado en las Ligas Patrióticas, y de la transformación de parte de él en movimientos fascistas. Así pues, aquella hibridación ideológica concibió una nación esencial e inmutable, con una misión y un destino, expresada en una «raza chilena», representada en el «roto» o "mestizo»; denunció la inmigración como efecto del imperialismo económico y como causa de la pérdida de la «unidad racial»; magnificó el período "pelucón», pretendiendo el restablecimiento de un Estado "de tipo portaliano», de autoridad fuerte, centralista y supuestamente representativo del «alma chilena»; hizo una interpretación decadentista de la historia chilena posterior al "peluconismo»; y, por supuesto, fue tan decisivamente antijacobina como desconfiada del liberalismo representativo, por considerarlos a ambos fuerzas disolventes de la nación.

$9 \quad$ Derivado de la costumbre de trabajar al aire libre, se perfiló como la representación pictórica, a través de la pintura, el grabado o el dibujo, de un espacio natural o urbano, frecuentemente con figuras.

10 No en vano el fundador de la Academia de Pintura, Alejandro Cicarelli, declaró en el discurso de apertura del 7 de marzo de 1849: «Si los hijos de la Patria derramaron su sangre en los campos de batalla para asegurar su independencia i su grandeza, las bellas artes tienen la misión de fecundar esta semilla de virtud i patriotismo, ilustrando por medio del arte las hazañas de estos valientes. Asi consiguen las naciones ser respetadas por sus vecinos i estimadas la posteridad, porque el arte es la trompa de la gloria, que ensalza la virtud donde la encuentra, la levanta i la conduce al templo de la inmortalidad» (cit. en Nordenflycht, 33).

11 Distinta del pensamiento liberal, socialista y socialcristiano, aunque con oscilaciones y diferencias internas suficientes —entre nacionalismo y conservadurismo- para engendrar luego diferentes tiendas políticas. Poco teórica, más polemista, criticó a la oligarquía como responsable del retraso material y espiritual del país y propició una reforma educativa que extendiera los valores de la nacionalidad, así como una industrialización que disminuyera la dependencia económica chilena del capital extranjero (Cristi y Ruiz, 17-66; Maldonado y otros, 37-49; McGee 11-25, 59-77; y Muzzopappa, 239-255). 
Evidentemente, el fetiche de la unidad nacional — territorial, racial, cultural- fue una constante en la historia de esta ideología, de manera que la interpretación del paisaje fue reelaborada en esa clave y así convertida en uno de los valores supremos, en tanto su vindicación simbolizaba la rehabilitación de un orden natural intemporal, mientras que su integridad simbolizaba la indivisibilidad e indisolubilidad de la nación. Aun cuando en los años treinta y cuarenta el nacionalismo se asociara con el fascismo, en los cincuenta y sesenta con el hispanismo y nuevamente con el militarismo desde fines de los sesenta (Valdivia, Nacionales y gremialistas, 203-240), la dependencia entre nación y paisaje permaneció tenaz en su discurso.

Ciertamente, pero con matices, el nacionalismo concibió el paisaje como una objetivación del territorio y una alegoría de la nacionalidad: su defensa, por tanto, implicaba la defensa de la «raza» o de la «chilenidad». Si desde el imaginario conservador y la estética tradicional — también parte del discurso cultural nacionalista- el paisaje era un refugio apacible y cómodo para la mirada y la vida, o bien una evocación de glorias pasadas, desde el vértice político del nacionalismo el paisaje comparecía como un elemento más proactivo y en peligro permanente.

Y fue ese vértice el que se intensificó con las transformaciones ocurridas al Chile tradicional en la segunda mitad del siglo XX, especialmente las que afectaron al mundo rural con la Reforma Agraria. La nostalgia por un mundo señorial, católico y tradicional —es decir, por una sociedad jerárquica y de identidad estamental-territorial, por una cultura cristiana y paternalista, por una ciudadanía restringida y por la vida de campo que había amparado su estructura social y valórica-, rebasó su habitual marco cultural para adentrarse firmemente en la enunciación política. Si la agudización de la lucha partidaria a comienzos de los años setenta repuso descarnadamente el carácter político de la controversia cultural, el discurso nacionalista-conservador afrontó ese combate apelando instintivamente al reservorio simbólico tradicional.

Por supuesto, esa politización de la matriz cultural nacionalista-conservadora tendió a politizar tenuemente la semántica de su imaginería. Ello porque su iconografía histórica, estelarizada por militares, élites o «grandes hombres», era contestada por la «alegoría de las luchas del pueblo y sus esperanzas» (Cleary, 194), típica de la figuración izquierdista que se apoderaba de los espacios públicos, especialmente de los muros ${ }^{12}$. Asimismo, su comodidad con las representaciones clásicas del paisaje chileno, asociado al campo del valle central (bucólico, épico o folclórico, de patrones donairosos e inquilinos trabajadores o mundanos, todos satisfechos de su oficio y posición social) $)^{13}$, era contradicha por la reestructuración de la propiedad, la sindicalización y agitación campesina, así como por el empuje de la estética obrerista y del trabajador urbano.

Y es que la cultura política del nacionalismo-conservador en el cual dichas representaciones habían configurado su significado, lo había llevado a «folclorizar» la cultura

12 Habitualmente asociando a la derecha con la clase alta y representándolas en cuerpos gruesos que comían hasta hartarse o que se apropiaban de las ganancias del trabajo ajeno, o asociándolas al arcaísmo estético y al desinterés social, como hizo el Manifiesto del Movimiento de Integración Plástica Chilena de 1953, al pretender «Luchar en contra de los sectores artísticos retrógrados y cosmopolitas, que hasta ahora han mantenido el arte y al artista plástico nacional al margen de nuestro pueblo» (Castillo, Puño y Letra, 64-136).

13 Durante la Reforma Agraria freísta y allendista, la representación campesina del cartelismo de izquierda también explotó el sentimiento de nostalgia —familias sobre carretas en un atardecer, por ejemplo-, pero para simbolizar el aislamiento y el atraso tecnológico y social del campo chileno (Vico, y Oses, 132). 
campesina y popular, purgando su contenido mestizo, indio o "roto» en favor de versiones estilizadas, estetizantes y blanqueadoras (hispanizantes) de música, literatura o gráfica ${ }^{14}$; y tras reivindicar al «roto» como categoría ideológica a comienzos de siglo, había terminado por sustituirlo por el huaso como arquetipo nacional, reservando al primero para ocasionales evocaciones de heroísmo o picardía. Es más, esa reducción de la cultura nacional a la cultura rural y del paisaje chileno al paisaje campesino de la «zona huasa» (generalizando unas características regionales), devino una idea esencialista de la derecha, aunque también permeara otros proyectos culturales, los cuales, eso sí, la combinaban con diversos grados de americanismo.

De tal manera que aquellas imágenes, que de algún modo hablaban de un orden social tradicional que moría, se convirtieron, por ello, en los años setenta en algo más que decoración o ilustración. Se cargaron de un sentido de trinchera.

De hecho, podría pensarse que ese sutil sentido de defensa y control social que adquirieron las representaciones culturales de la nación, y en particular el «paisaje nacionalista-conservador», se intensificó con la visión militar del territorio. La impronta prusiana había sido suficientemente fuerte como para que militares y civiles nacionalistas apreciaran al paisaje como un organismo en lucha y peligro. Como enseñaba el entonces profesor de la Academia de Guerra del Ejército, Augusto Pinochet:

La geopolítica considera al Estado como un organismo supraindividual y, como tal, un organismo vivo que se halla empeñado en una lucha constante por la existencia. La Tierra, por su configuración, está dividida en cierto número de espacios que son el escenario de estas luchas entre los Estados. Esta lucha condiciona una política encadenada al espacio, con leyes determinadas y constantes que afectan, en forma permanente, a los pueblos que actúan en una región, a medida que van haciendo su aparición en la Historia $(31)^{15}$.

Por otra parte, esa visión comenzaba a verse también influida por la Doctrina de Seguridad Nacional (en adelante DSN), que se superponía al «ibañismo» castrense clásico, reforzando el concepto organicista de nación, su dependencia del Estado, la de éste respecto de las Fuerzas Armadas y la amenaza de los enemigos, tanto internos como externos $^{16}$. Mientras ese nuevo tipo de militarismo incrementaba su ascendiente al interior del nacionalismo civil, al convencerse de que las Fuerzas Armadas eran el único agente social capaz de acabar con la Unidad Popular, la lectura defensiva del territorio comenzó a dominar las interpretaciones del paisaje. Este "paisaje-escudo» se hizo parte del léxico e imaginería "patrióticos» con que la oposición nacionalista y de derechas confrontó al allendismo "antichileno».

No en vano Sergio Onofre Jarpa declaraba entonces, como dirigente del Partido Nacional:

[...] la política externa es el más fuerte vínculo de unidad nacional y está íntimamente ligada a la defensa del espacio territorial. A su vez, el instinto territorial es el mayor factor de acercamiento y de solidaridad entre los hombres y los animales [...] Una política externa nacionalista debe significar para Chile un esfuerzo por liberarse de dependencias

14 Dentro de un proceso general de estilización desde la academia y el Estado, posteriormente acentuada en dictadura, no exento de pugnas (Donoso, 25-40).

15 El original de este libro data de 1968.

16 Mientras que el «ibañismo» se caracterizaba por su desprecio de los políticos y preferencia por los tecnócratas, por su proclividad a un Estado socialmente comprometido pero autoritario (Valdivia, El golpe después del golpe, 21-44). 
extranjeras; una firme voluntad de defender su soberanía, sus recursos y sus posibilidades; la búsqueda de aliados para contrarrestar la presión que se ejerce sobre sus fronteras; el incremento del intercambio y una clara proyección de su expansión futura hacia el ámbito del Pacífico (42-44).

De forma que el constructo ideológico que accedió al poder con el golpe militar asumió la tarea doctrinaria de recrear la identidad nacional recurriendo, entre otros expedientes simbólicos, al ícono paisajístico tradicional, ya tratado por la interpretación geopolítica como una especie de baluarte contra la supuesta amenaza disgregadora marxista. Habiendo llegado este paisaje a constituir un patrimonio cultural de las derechas, lo que hizo la dictadura fue terminar por convertirlo en su patrimonio político.

\section{EL DESAFÍO «POSMARXISTA»: REINVENTAR LA PATRIA DESDE EL PAISAJE}

El desafío posterior a 1973 fue reelaborar la narrativa de la "patria», de manera no sólo de ampliar la base de sustentación del nuevo imaginario en el poder, sino que también de superar la contradicción de que dicho imaginario se sustentara en una exclusión ideológica y cultural. Se trataba de presentar como aceptable e imprescindible el nuevo orden, a la vez que encadenarlo a la idea de un valor invariable. Se trataba de reinventar una tradición.

En efecto, además de autorrepresentarse como redescubrimiento o restauración del «alma nacional», el hecho de fuerza del «11» generó también el imperativo de reemplazar los rastros de sedición, quebrantamiento y dictadura por los ideales de misión, salvación y regeneración política. Con ese imperativo, el paisaje fue exhortado por la cultura oficial —en tanto presupuesto de integración y de genuina «chilenidad»— para tres propósitos: primero, para reforzar el reconocimiento o vinculación de los adherentes con el proyecto cultural de las derechas; segundo, para desacreditar representaciones alternativas de la identidad campesina, popular y nacional (desmovilizando así, simbólicamente, a los vencidos); y tercero, para legitimar el nuevo orden político como expresión de un determinado «orden natural» ${ }^{17}$.

Por supuesto, aquella invocación del paisaje - perceptible, por ejemplo, en algunos impresos de la Editora Nacional Gabriela Mistral ${ }^{18}$ - ocurrió dentro de la embestida comunicacional y cultural del gobierno militar, gestionada principalmente por ex militantes nacionalistas. Por tanto, la obra editorial fue complemento de una "operación de limpieza», que mezcló cosas tan disímiles como el aseo de aceras y jardines con el

17 Paralelamente, el régimen inició desde 1974 la reorganización político-administrativa del territorio nacional - Regionalización-, bajo el eslogan de la descentralización y el imperativo de la Doctrina de Seguridad Nacional. Pretendía mejorar la «justicia social», la "descentralización del sector público», la «seguridad nacional», el «crecimiento económico»y la «unidad nacional». Y aunque retomó el interés por la integración nacional de las teorías modernizadoras previas, fue sobre todo un reordenamiento territorial (Boisier, 85-92).

18 Desde su creación en 1973 (a partir de Quimantú, editorial de la UP), los primeros directivos intentaron reflotarla económicamente y sumarla, desde el ámbito educativo y divulgativo, a la restauración de la «chilenidad». Pero primó el enfoque neoliberal y fue debilitada y privatizada en 1976. Pese a ello, fue un proyecto editorial oficial que contribuyó en parte, con sus limitaciones y peculiaridades, a la difusión de los valores culturales del régimen. 
blanqueo de paredes (de los murales de la UP), la destrucción de monumentos (como el del Che Guevara en San Miguel), la prohibición de usar el color negro u «otros tonos violentos» en las fachadas, el fomento de un vestuario más formal y del pelo corto y la barba rasurada entre los hombres. Asimismo, esa tarea editorial fue también complemento de una "campaña de restauración» igualmente diversa, que incluyó la reparación de casas de campo, la instalación de estatuaria militar, la promoción de la artesanía, de los «grandes maestros» de la pintura chilena y de la música folclórica «apolítica», como veremos más adelante (Errázuriz, 139-150). Así pues, en el fomento de esa estética privada y pública tradicionalista, el paisaje sirvió para metaforizar una concepción de nación y un presente político. Sirvió más para glorificar al Estado que a la naturaleza, aun cuando se invocaba en nombre de ésta. Se convirtió en icono de admiración, como sublimación de la devoción a la patria.

Por supuesto, como el resto de los dispositivos visuales oficiales, las ilustraciones de la ENGM no necesariamente prestaron tal servicio ideológico de manera individual, masiva ni decisiva. Tampoco fue el resultado necesario de intencionalidades autorales o de que los libros que las alojaban se dedicaran especialmente a ello. Más bien, aunque fueron escolta visual de los contenidos específicos de cada publicación, las ilustraciones que incluyeron motivos paisajísticos participaron de algún modo de la «semiósfera autoritaria» ${ }^{19}$ que reclamaba al paisaje como acrisolador de la nueva "chilenidad». Ya fuera desde la serie "El Patrimonio cultural chileno", desde la "Colección Nosotros Los Chilenos» o desde proyectos interrumpidos, como "Expedición a Chile», de manera indirecta y dentro de libros consagrados a diferentes temas dichas ilustraciones connotaron sus significados dentro de aquella narrativa: lo hicieron contribuyendo a la valoración política del espacio regional, a la invocación de la paisajística tradicional y a la interpretación del territorio en la clave de la geopolítica y de la DSN.

\section{VALORACIÓN POLÍTICA DE LO LOCAL}

En rigor, la interpelación del paisaje local fue, antes que un argumento estético o geopolítico, un argumento histórico - como espacio de un pasado a reivindicar-, para asentar el nuevo sistema político sin Parlamento ni partidos. El sacerdote Osvaldo Lira lo había expresado en el compendio Pensamiento Nacionalista: "Nuestra tradición no ha sido nunca la de los partidos políticos, sino una tradición de las familias, municipios, regiones, gremios y corporaciones. Son estas sociedades, por consiguiente, el fundamento sobre el cual deberá levantarse el edificio futuro de nuestra entidad política restaurada» (cit. en Cox y otros, 59-63).

Palabras como ésas resumían la tradición historiográfica conservadora que los ideólogos del régimen habían aprendido de Eyzaguirre y del propio Lira y que aportaba una explicación histórica para la dictadura. Para ellos, la sociedad colonial habría sido el momento privilegiado en el que se formó y cuajó la nacionalidad chilena. Se trataba de un período formador de un carácter fuerte, hecho de voluntad, acción, nobleza, austeridad,

19 En sentido laxo, la semiósfera es entendida como universo semiótico o sistema de signos, significados, códigos generativos y de uso creados por una cultura, que posibilitan una acción sígnica específica. En este caso, la construcción «autoritaria» del paisaje (Lotman, 23-42). 
honor y fe. Tras esa fase, encumbrada por el «Estado en forma` de los decenios pelucones, Chile se había visto sumido en una larga etapa de decadencia, de repliegue político y agotamiento, en suma, de «desnacionalización".

De forma que, por la vía de ese argumento, la región — no como unidad administrativa contemporánea sino como el espacio del Chile tradicional—incrementó su valoración política en el discurso oficial. De manera que la geografía local (generalmente rural) adquiría mayor valía con ese relato de trasfondo, que veía en ella la heredad de las antiguas familias y municipios, la comarca de la sociedad ancestral, frente al lugar de los sindicatos, los partidos y la política que representaba la urbe moderna.

Una segunda vía que dio mayor sentido político al paisaje local en el discurso oficial fue la de agudizar su «condición» de raíz y expresión de la idiosincrasia de sus paisanos. Uno de los ejercicios más claros al respecto (figura 1) fue el libro dedicado a la juventud Perfiles del Chile Joven:

La naturaleza tan cambiante de norte a sur, moldea la vida de los chilenos. Cada clima y cada paisaje forja caracteres que responden a la sequedad del desierto, a la intranquilidad del mar y la fecundidad de la tierra sureña. Es así como la vida del joven nortino está asociada a la vida del desierto. Los que nacieron junto al Pacífico, en una tierra exótica, con un paisaje pétreo, son recios y temerarios. La vida del joven sureño está marcada por el clima lluvioso en que le tocó nacer. La fertilidad de la tierra los hace ser amistosos y hogareños. Por el contrario, los que nacieron y crecieron en la ciudad, donde la vida es agitada, son más reservados y solitarios [...] Según sea el lugar en que le tocó nacer y los trabajos que realiza para dominar la naturaleza, el chileno toma actitudes diversas, que forjan un carácter propio, cambiante de región en región (D’Alburquerque y Rostagno, 8-9).
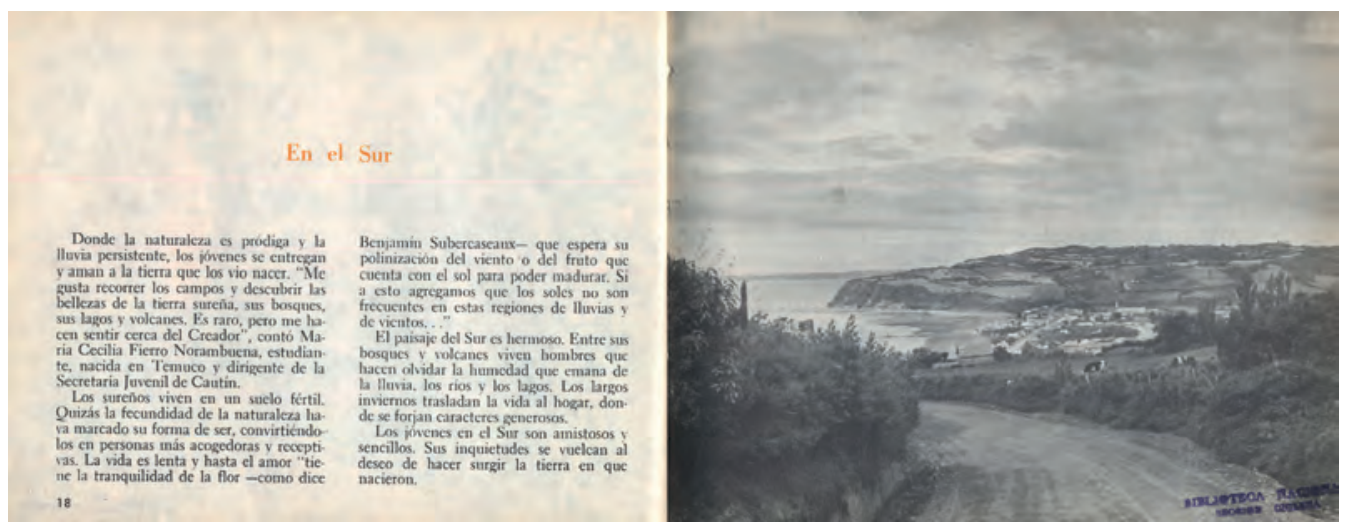

Figura 1. D’Albuquerque y Rostagno, 18. Asesor artístico: Enrique Bunster. Diagramación: Departamento de Libros.

La tercera vía que incrementó el valor político del paisaje local — probablemente más intensa que las anteriores - fue la de considerarlo un fragmento, parte de una totalidad especial. En esta modalidad, el paisaje local, solo o como escenario de un hecho histórico o cultural, comparecía como una pieza que únicamente realizaba su sentido cabal en el 
conjunto del país. Su valor residía menos en sí mismo y más en dar diversidad al territorio nacional unitario, el verdadero valor supremo del Gobierno ${ }^{20}$.

Así pues, el libro Los Pioneros mostró las virtudes de espacios geográficos diferentes y de sus respectivos habitantes, especialmente de los extremos como la zona magallánica o el desierto minero (Los pioneros, 6-30). El libro Océano Pacifico, al explicar las posibilidades económicas del mar, retrataba a los pescadores artesanales de Coquimbo, a los operarios que embarcaban el cobre y a sujetos de otros parajes con el supuesto implícito de que tal variedad procedía de la variedad natural (Orrego, 50-51). Asimismo, el texto Las nuevas regiones de Chile incluyó descripciones, coronadas por imágenes que exhibían alguna peculiaridad regional, como en Arica, Araucanía o Coquimbo (Apey e Ibáñez, I:13-41 y II:47). Por su parte, la reimpresión de Visión de Aysén. Expediciones del explorador Juan Augusto Grosse demostró el interés compartido con el autor de dar a conocer la desconocida zona austral y fomentar el orgullo de que tales parajes formaran parte del país. De allí que las imágenes que combinaban paisajes y símbolos patrios (figura 2), aunadas a "textos patrióticos», adquirieran especial sentido. También el prefacio original de la primera edición de 1955, escrito bajo el segundo mandato de Ibáñez por el entonces intendente de Aisén, el General de Carabineros (R) Luis Marchant González, adquirió un nuevo significado en 1974:

Conocedor profundo de este pedazo de tierra chilena, Grosse nos conduce, a través de bien moduladas escenas, en un raudo viaje por esta verdadera tierra de ensueño que llamamos Aisén y que todo chileno debiera conocer pues en ella comenzará mañana sus albores el Chile Nuevo, rico y pletórico de energías, que nuestros gobernantes ansían crear [...] Nos conduce a través de sendas, de caseríos, y en medio de campos ‘bordados de flores» nos hace llegar al pie de una riquísima mina [...] Mientras usted, lector, lo lee, piense que en lo más íntimo de la región austral de Aisén hay un hombre que sentado a la orilla de un lago, que su fe visionaria ha descubierto, extasiado mirando la bandera chilena que él ha plantado en la arena que traviesa juguetea a sus pies, pierde su mirada en el infinito, tal vez añorando una Patria más grande, más fecunda, más portentosa (Grosse, 11).

20 «Siendo el nacionalismo chileno de índole esencialmente libertaria [declaraba en Objetivo Nacional de Chile], el medio cultural deberá posibilitar la expresión de todas aquellas manifestaciones culturales diversas, que surjan como iniciativas de personas, grupos o regiones, evitando una masificación inconveniente, pero velando asimismo para que la cultura jamás sirva de pretexto para atentar contra la tradición, unidad e identidad patrias» (Objetivo Nacional de Chile, 47). 


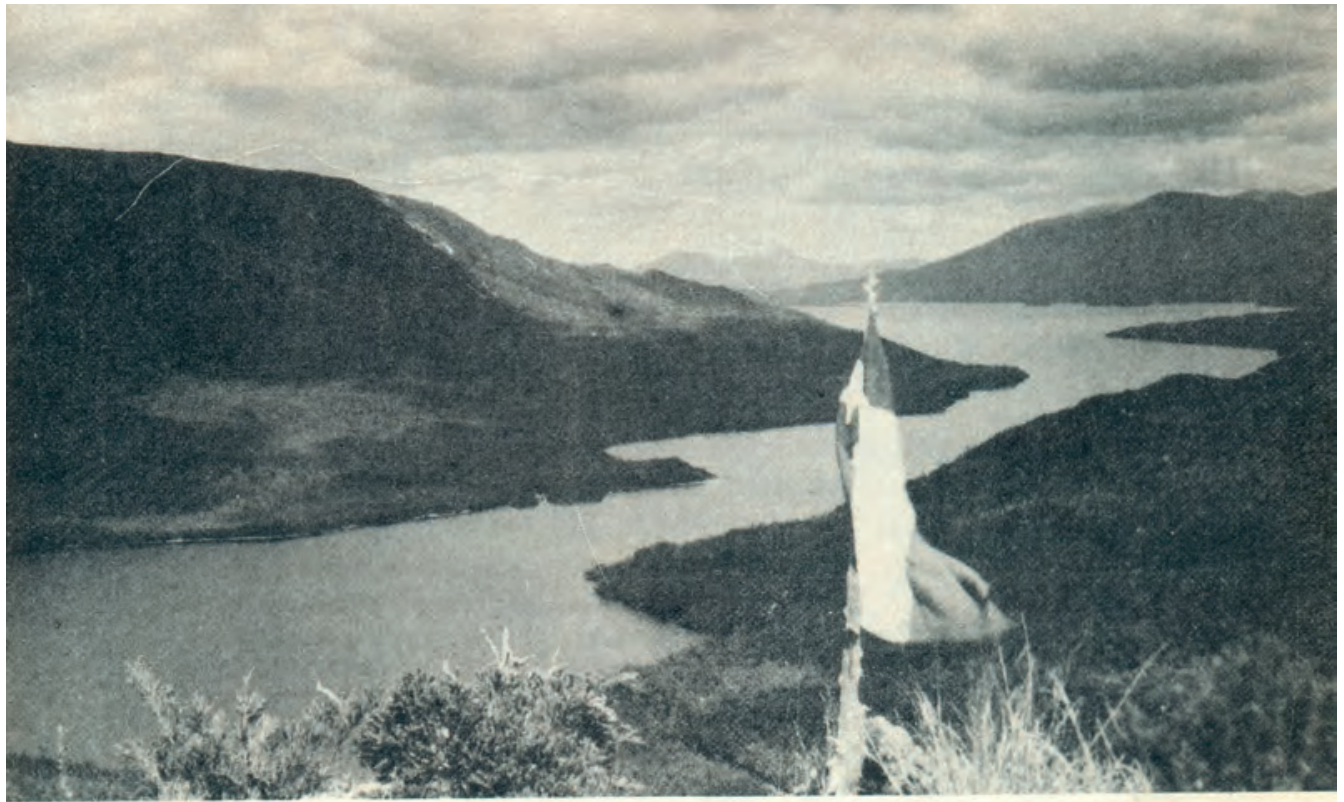

Península TAITAO, lago JUAN ANTONIO RIOS

Figura 2. Grosse, 109.

En suma, estas interpelaciones subyacentes al paisaje local como espacio de la antigua sociedad, como productor del temperamento chileno o como factor del territorio nacional - fin último del régimen- hicieron que las ilustraciones lo perfilaran, en cierta forma, como una esencia tras lo manifiesto, como un medio para llegar al «alma chilena»: porque atesorando las relaciones sociales premodernas, posibilitando y diversificando la patria y, sobre todo, «madurando» a su gente, el paisaje permitía inscribir la sociedad y el Estado autoritario en el orden de la naturaleza. En tanto se le suponía un vínculo íntimo con sus habitantes, el paisaje local agudizó su valor político, transitando de expresión de la idiosincrasia regional a mecanismo indirecto de acceso a la psicología del pueblo chileno.

\section{INVOCACIÓN DEL PAISAJE TRADICIONAL}

Como es sabido, el expediente del paisaje operó en el contexto de la insistente asociación —ahora gubernamental- entre «chilenidad» y cultura «huasa ${ }^{21}$. De aquí que las repre-

21 Dedicados a promover la cultura folclórica estuvieron el Departamento de Cultura de la Secretaría General de Gobierno, transformada en Secretaría de Relaciones Culturales en 1977, y el Departamento de Extensión Cultural. La primera fue parte de las organizaciones creadas para trabajar con la base social. Su origen fue el Departamento Cultural de la Secretaría General de Gobierno. Partió conduciéndolo Germán Domínguez, ex militante del Partido Nacional, reemplazado por Benjamín Mackenna en 1977, integrante del grupo musical «Los Huasos Quincheros» y de tendencia nacionalista, a su vez sustituido por Francisco Javier Alcalde Pereira en 1980 y, finalmente, por Juan Guillermo Prado en 1984, investigador de las tradiciones culturales chilenas y también nacionalista. El Departamento de Extensión Cultural 
sentaciones del paisaje comprometieran en parte su semántica con el entorno simbólico que crearon los programas televisivos y radiales ${ }^{22}$, las agrupaciones musicales promovidas (incluso como embajadoras culturales en el extranjero, como en el caso de «Los Huasos Quincheros»), los festivales y concursos folclóricos, los campeonatos de cueca, las exposiciones artísticas itinerantes, los actos públicos con artistas del género, la obligatoria enseñanza de cueca en la escuela, la entrega gratuita de grabaciones con música folclórica a colegios y municipalidades y, naturalmente, la declaración de la cueca como danza nacional en $1979^{23}$.

Era difícil que este fuerte sesgo nacionalista-conservador de los civiles y militares involucrados en las secciones culturales no tiñera las invocaciones al paisaje con dicha «tradición huasa». Con ella, el valle central repuso su señorío, apareciendo como patrimonio común y auténtico del país y no sólo como la forma de vida de un grupo ${ }^{24}$, pretendiendo encarnar el pasado fundador y no sólo una parte de la historia y figurando los principios de jerarquía social y autoridad ${ }^{25}$, así como la idea de nación trascendente.

Las imágenes de la ENGM entablaron un diálogo con dichas demandas, sumándose al énfasis y consagración de la «zona huasa», si bien con menos entusiasmo que respecto del paisaje regional e incluso tal vez de manera mecánica. Pero algo aportó. Por ejemplo, el librito Chile. Galería artesanal, de 1975, eligió para su portada (figura 3) la fotografía de un conjunto de artículos usados por el huaso: manta, sombrero, cinturón, espuelas, estribos, lazo y hasta el cacho del buey para el brindis. Pero no eran los aparejos del campesino, sino del patrón. Probablemente no sólo porque se tratara de destacar el refinamiento artesanal de las piezas, sino porque se les otorgaba una primacía congénita. Quizás dicha elección expresaba la familiarización (por vida cotidiana, influencia profesional o cultural), con la experiencia y estética de los hacendados de la zona central — caballo, costumbres y aperos - y su naturalización como dispositivo monopólico de la imaginería y el «ser〉 nacional.

del MINEDUC también surgió en 1977, a partir de una reforma a dicho ministerio. Durante los primeros meses fue dirigido por el nacionalista Enrique Campos Menéndez y después por Germán Domínguez Gajardo, hasta el fin del régimen (Silva, 112-113).

22 Entre 1978 y 1980 se emitió el programa radiofónico «Lo que cantan las canciones» en Radio Nacional, dirigido por Germán Becker, y desde 1981 el programa «Chile y su música», dirigido por Jorge Oñate y Jorge Rencoret, ambos dedicados al folclore nacional. Asimismo, se auspició el programa televisivo «Chilenazo", conducido por el mismo Rencoret, durante dos temporadas en los años ochenta.

23 Decreto Supremo no 23, 18 de septiembre de 1979, Diario Oficial 6-11-1979, p. 4. Los considerandos resumieron el ambiente oficial de patriotismo que permitía esa reducción identitaria: «[...] la cueca constituye en cuanto música y danza la más genuina expresión del alma nacional; que en sus letras alberga la picardía propia del ingenio popular chileno, así como también acoge el entusiasmo y la melancolía; que se ha identificado con el pueblo chileno desde los albores de la Independencia y celebrado con él sus gestas más gloriosas y, que la multiplicidad de sentimientos que en ella se conjugan reflejan, no obstante la variedad de danzas, con mayor propiedad que ninguna otra el ser nacional en una expresión de auténtica unidad» (Guzmán, 59).

24 Todavía el año 2000, la derecha reclamaba la primacía del folclore huaso. Con motivo de la gala del cambio de mando, la diputada UDI María Angélica Cristi se quejó en la sesión parlamentaria del 14 de marzo: «Tal presentación fue de muy mal gusto, porque no representaba en nada a quienes siempre han sido los más auténticos exponentes de la música chilena. Si bien entiendo que la música chilena no sólo debe ser mostrada por huasos, por gente del norte o de Chiloé, esa ocasión sí lo ameritaba [...] En ese sentido, solicito que se oficie [...] a las nuevas autoridades que estarán a cargo de la cultura del país [...] para que nunca más se presente, en especial cuando queremos mostrar nuestra música al extranjero, un acto folclórico que no corresponda a lo que es lo intrínseco, lo básico, lo fundamental». Su oficio posterior fue apoyado por los diputados RN Alberto Cardemil, Haroldo Fossa y Mario Bertolino (Guzmán, 65).

25 «[...] será tarea prioritaria del nuevo Estado, el robustecimiento del principio de autoridad y de respeto a las jerarquías» (Objetivo Nacional de Chile, 10). 


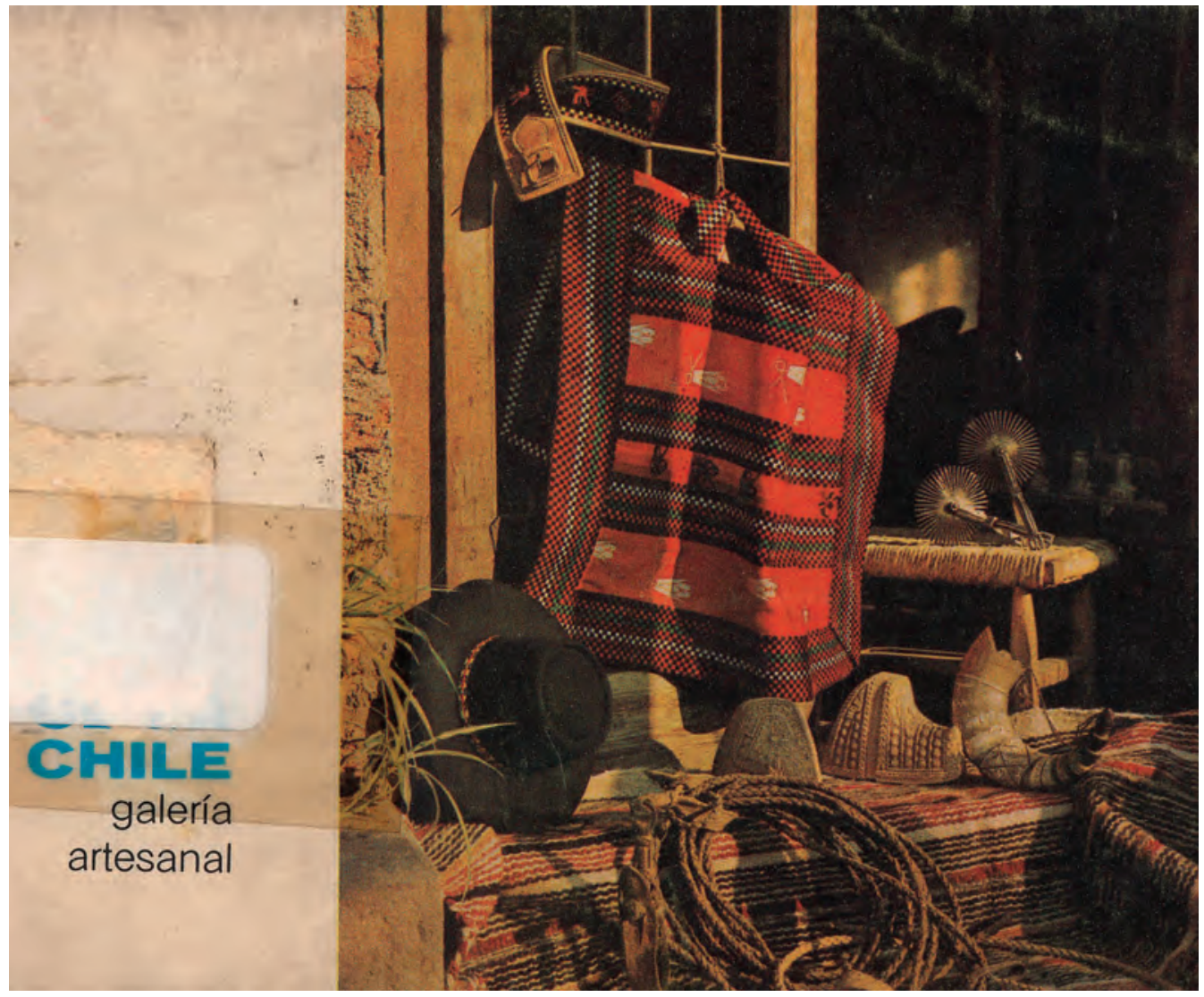

Figura 3. Galería artesanal, portada.

En la acción contraria, mostrando cómo el marxismo había "profanado» el campo, la portada de la novela Llegarán de noche, de 1976, exhibió la entrada de un fundo tomado por militantes y campesinos, luciendo banderas y carteles con los íconos y eslóganes de la izquierda (figura 4). Éste era el caso contrario, es decir, la ejemplificación del paisaje mancillado por la izquierda, del ataque a los principios centenarios encarnados en el «suelo vital» por el caos y la indisciplina social. Como si fuera capaz de simbolizar el estado espiritual de la nacionalidad (recuérdese la correspondencia entre naturaleza y pueblo), aquella imagen sintomatizaba la patria descompuesta, la trivialización de la nación. 


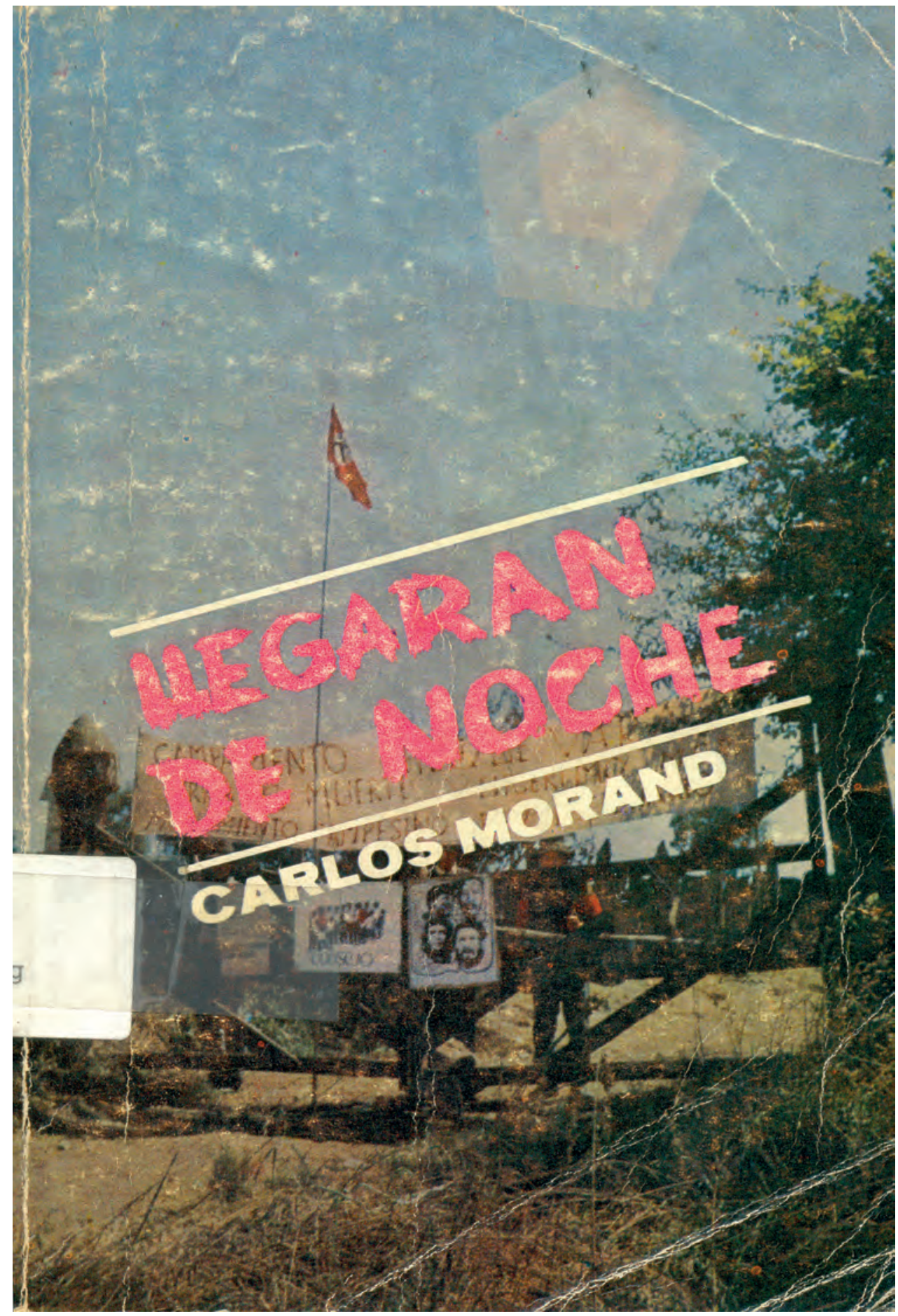

Figura 4. Morand, portada. 


\section{EL PAISAJE EN MANOS DE LA GEOPOLÍTICA Y LA DOCTRINA DE SEGURIDAD NACIONAL}

Como es conocido, en la redacción del Bando $\mathrm{n}^{\circ} 5$ del 11 de septiembre y la Declaración de Principios de marzo de 1974 participaron civiles, entre ellos militantes del Movimiento de Acción Nacional y del Partido Nacional, como el asesor cultural de la Junta, Enrique Campos Menéndez. Por ende, no es casual que el último documento aclarara «el nacionalismo chileno, más que una ideología, es un estilo de conducta, la expresión genuina del ser de la Patria y del alma de su pueblo»; o que anunciara la configuración de «un Sistema Nacional de Planificación», que superara «la falta de coordinación entre la planificación del Desarrollo y la de la Seguridad Nacional, integrando a esta como parte vital de un Desarrollo Global Nacional» (19-20).

Pero fueron las publicaciones Política cultural del Gobierno de Chile, de 1974, y Objetivo Nacional de Chile, de 1975, las que relacionaron de manera más concreta la seguridad nacional con los supuestos culturales de la dictadura. Este último señaló:

La Seguridad Nacional es de responsabilidad de cada uno y de todos los chilenos; por tanto, debe inculcarse este concepto en todos los niveles socio-económicos, a través del conocimiento concreto de las obligaciones cívicas generales y específicas en relación con el área del Interior; por el estímulo de la escala de valores patrios; por la difusión de los alcances culturales propios en la variada gama del arte autóctono, y por la orientación y comentarios permanentes de las tradiciones históricas y del respeto a los símbolos que representan la Patria (15-16).

Ciertamente, la DSN había complementado la geopolítica de herencia alemana, así como había venido a llenar el vacío doctrinario dejado por un constitucionalismo formal en las Fuerzas Armadas, devolviéndoles su autovaloración y sentido de superioridad sobre la sociedad civil, toda vez que la teoría le entregaba la responsabilidad por la sobrevivencia de la nación frente a sus enemigos internos y externos. La autonomía respecto del mando civil y su anticomunismo eran componentes previos, pero el axioma de la unidad nacional, especialmente territorial, fue exacerbado con el nacionalismo de posgolpe y con la geopolítica militar, al punto de pautear el discurso sobre las relaciones entre Estado, población, territorio y paisaje. Este último fue subordinado, en sus connotaciones estéticas e históricas, en favor del desarrollo del Estado, reflejo del poder de la nación.

En dicho esquema, el paisaje chileno - así como el relieve, la hidrografía, la fauna, la flora y el clima- se volvió la mera superficie del «espacio vital» de la nación. En las operaciones anteriores (valoración política del paisaje local o rehabilitación del paisaje tradicional), el paisaje era un ser casi viviente que tomaba «energía» de sus habitantes tanto como les traspasaba la suya, en una comunicación identitaria entre naturaleza y población. En cambio, bajo la clave geopolítica y de la DSN, traspasaba esa cualidad de organismo vivo al Estado. Se convertía en el terreno de sus posibilidades y constricciones, en facilitador de su grandeza o coautor de su decadencia. Pero, en cualquier caso, aparecía como expresión subalterna del Estado.

En otro aspecto, el análisis geopolítico refrendó la preferencia por el valle central de las interpretaciones anteriores del paisaje: 
Las características geofísicas del Estado de Chile — repetía Pinochet en la cuarta edición de su Geopolítica - señalan que sobre su territorio existen numerosos «Núcleos de Atracción` que se distribuyen a lo largo de su extensión; pero estos núcleos diseminados ampliamente de norte a sur o viceversa, van aumentando intensamente su cantidad hasta llegar a formar casi un solo núcleo entre los ríos Aconcagua y Bíobío; más al sur, como lo hemos expresado, estos núcleos nuevamente se van diversificando hasta llegar al Canal de Chacao. [...] Este hecho geográfico nos permite afirmar que el «núcleo vital de Chile», geofísicamente, está sólidamente asentado en mayor proporción entre los ríos Aconcagua y Bíobío y entre la Cordillera de los Andes y la Cordillera de la Costa (137).

Si el paisaje local había sido codificado como parte del todo nacional y puerta de la mentalidad popular, y si el valle central había sido apreciado como reducto del Chile tradicional, la clave geopolítica-DSN asoció el paisaje a los imperativos de futuro de un Estado vivo y «en crecimiento»: es decir, lo asoció a las fronteras, al desarrollo económico, a la expansión marítima y a la soberanía en los extremos geográficos; en definitiva, a la pretendida lucha por la existencia de la población chilena frente a las otras que disputaban la misma región continental. Con esa operación, el habitual sentido defensivo y tradicionalista del "paisaje nacionalista» (reactivo al paisaje subvertido de la izquierda) dio paso a la semántica ofensiva de la DSN.

Obviamente, dicha operación entroncaba con el diagnóstico nacionalista sobre la sistemática pérdida territorial del país en el trascurso de su historia ${ }^{26}$. Como respuesta, Chile debía recuperar, si no los territorios perdidos, al menos su influencia expansiva, credo divulgado desde diversos frentes comunicacionales y culturales. De hecho, para favorecer el reclamo sobre el "territorio chileno antártico", incluso editoriales privadas reeditaron obras como Breve historia de las fronteras de Chile, de Eyzaguirre, e hicieron lo mismo durante la disputa con Argentina por las islas del canal Beagle (reimprimiéndola por novena vez en 1979).

No extraña, entonces, la reiteración del mapa «Nueva visión de Chile», que, siguiendo el ideal de un país tricontinental (con posesiones en América, Oceanía y la Antártica), no sólo remachaba las posesiones sobre las islas del Pacífico y la "Antártica chilena»" sino que, triangulando esos vértices, proyectaba el territorio continental hacia una amplia zona de influencia en el Pacífico. Lógicamente, entre las publicaciones de la ENGM que divulgaron esa «visión» estuvieron los textos propagandísticos de la Junta, Primer año de la reconstrucción, de 1974, y Chile. 11 de septiembre de 1975. Este último incluyó fotografías del segundo aniversario, documentando cómo el decorado del escenario era, en versión gigante, el mapa de la «Nueva visión de Chile», que remataba al pie del proscenio con la declaración «Chile será una gran nación» (figura 5).

26 En el campo educativo, recuérdese el Atlas Geográfico de Chile: para la educación, del Instituto Geográfico Militar de 1985, que en su página 45 incluyó, bajo el título «Nuestros límites», cuatro mapas que mostraban una progresiva reducción territorial desde la Colonia, no contradicha con la expansión del siglo XIX.

27 Ya el decreto n 1747 de 1940 había establecido que ésta se ubicaba entre los meridianos $53^{\circ}$ y $90^{\circ}$ longitud Oeste de Greenwich, pero la firma del Tratado Antártico de 1959 había congelado esta demanda, por tanto, desde entonces la ONU no reconocía reclamaciones de soberanía. 


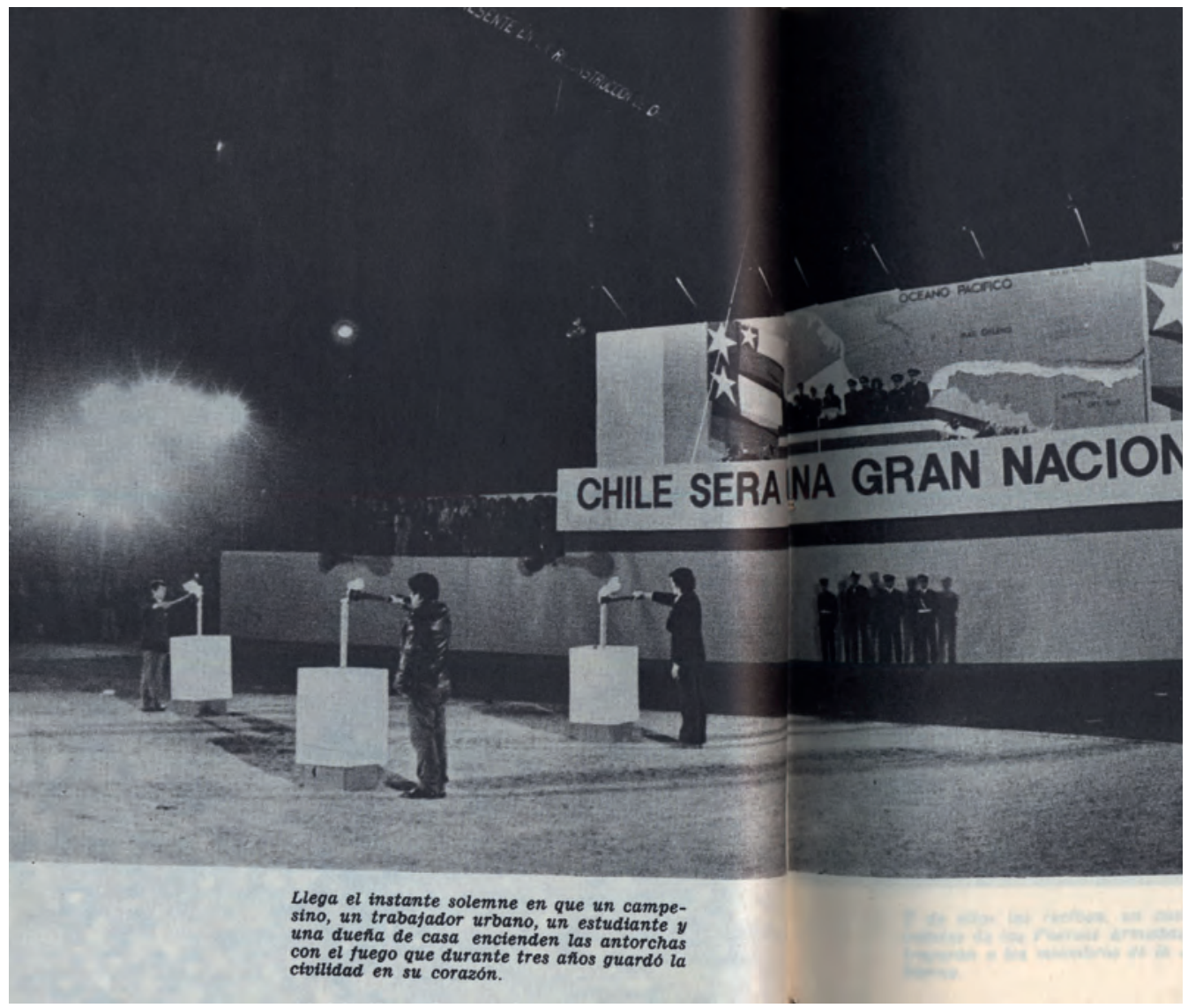

Figura 5. Chile. 11 de septiembre de 1975, 32-33.

Pero incluso libros no oficiales incluyeron aquella representación. Una versión algo más estilizada, por ejemplo, fue el motivo de la tapa de La participación de Chile en el sistema internacional, de Francisco Orrego, de 1974, mientras que el compendio de Memorias de Gabriel González Videla, de 1975, la introdujo con este epígrafe: "Nueva visión de Chile con las doscientas millas marítimas. La línea punteada en la fotografía [se trata en realidad de un esquema hecho a mano] señala el ensanchamiento del territorio nacional. (Creación de Enrique Campos Menéndez, Asesor cultural de la Junta de Gobierno)» (figura 6). Y el texto de página agregaba literalmente: "Chile, en esta nueva visión, deja de ser un país aislado, encerrado entre una altísima cordillera y el mar; ya no es una nación alejada del mundo, sino que se abre en horizontes tan amplios que ninguna otra puede tener» $(848$, los paréntesis son del original). 


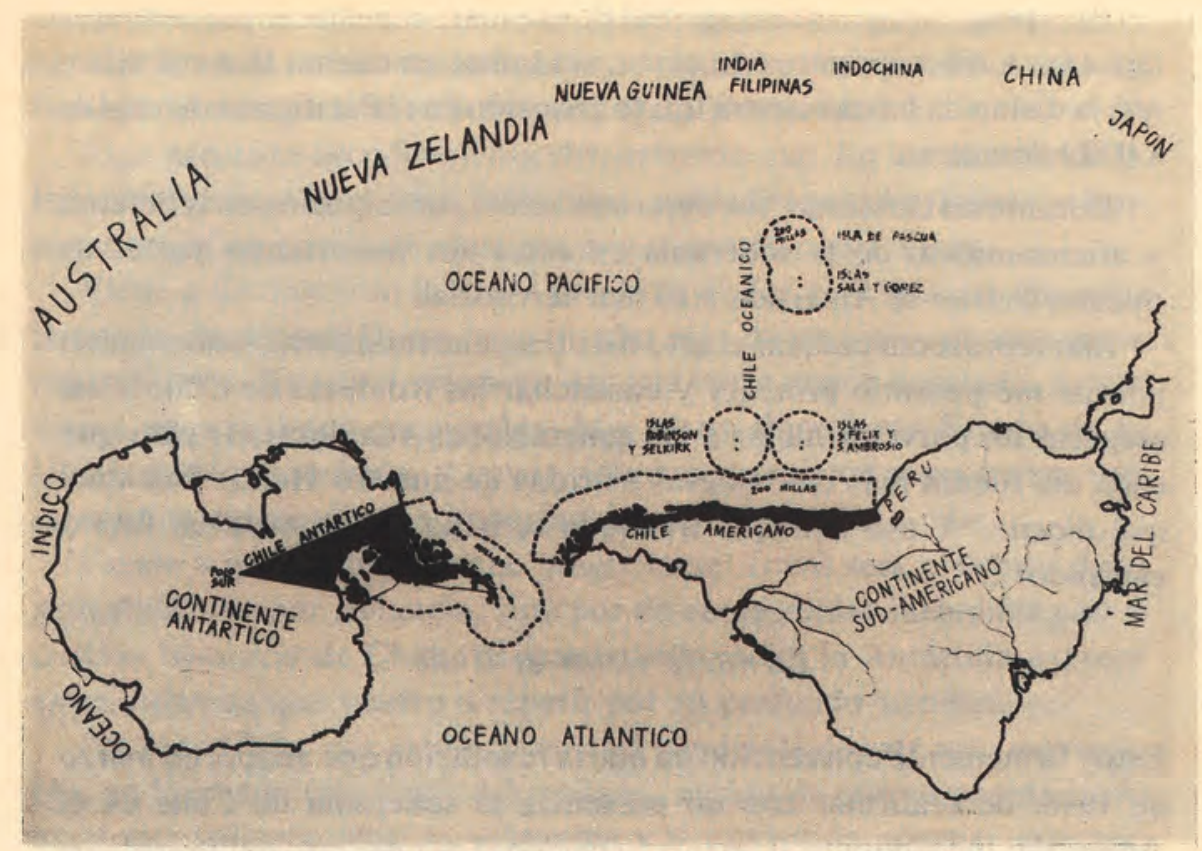

Nueva visión de Chile con las doscientas millas marítimas. La línea punteada en la fotografia señala el ensanchamiento del territorio nacional. (Creación de Enrique Campos Menéndez, Asesor Cultural de la Junta de Gobierno.)

hasta lindar con Japón, Australia, Nueva Zelandia y las islas de la Polinesia.

Chile, en esta nueva visión, deja de ser un país aislado, encerrado entre una altísima cordillera y el mar; ya no es una nación alejada del mundo, sino que se abre en horizontes tan.amplios que ninguna otra puede tener.

Queda así, también, proyectado el destino de Chile: el mar.

Tarea de los nuevos Gobiernos será darle a nuestro país las herramientas para conquistar este futuro grandioso que le ha sido abierto. Mi Gobierno plantó las bases para esta tarea futura. 
En definitiva, el paisaje fue tratado por la geopolítica y la DSN como irradiación de la unidad nacional y de la vitalidad del Estado, reflejada en la soberanía sobre los extremos geográficos y en la ampliación virtual de su zona de influencia. Ello complementó las otras operaciones de significación, aludiendo a la geografía como base del patriotismo o como patria misma.

\section{CONCLUSIONES: EL PAISAJE COMO ¿CAUSA`POLÍTICA Y COMO SABER}

Acorde al pensamiento militar y la ideología nacionalista-conservadora que lideró el control de los aparatos comunicacionales y culturales en una primera época, se repuso el «culto a la patria), se invocó la restauración de la «chilenidad y se hizo de la unidad nacional uno de los valores máximos del régimen. Ese predicamento resultó funcional incluso cuando la ideología neoliberal triunfó al interior de La Moneda (la cual también compartía en cierto grado los clichés nacionalistas), puesto que sirvió de cohesionador interno, de cara a los diversos grupos ‘golpistas`, y externo, de cara al resto de la población.

Ciertamente, aunque fue formulado por un grupo, dicho predicamento requería de un sustrato colectivo que permitiera que el proyecto fuera imaginado por una mayoría, por lo que una de sus condiciones de posibilidad fue la resignificación de algunos aspectos de la realidad y de las narrativas nacionales y nacionalistas ya existentes: por ejemplo, las metáforas paisajísticas de los símbolos patrios, el campo de la zona central como el ‘paisaje chileno', el paisaje como condensación del territorio, su inviolabilidad como resguardo de la nación y la politización de sus connotaciones históricas y estéticas.

La resignificación de tales relatos previos apuntó a la interpelación política del paisaje local con el argumento histórico (como espacio de la añorada sociedad ‘prepolítica), en tanto premoderna), con el argumento psicosocial (como formador y manifestación del temperamento chileno) y con el argumento geopolítico (ser componente del todo nacional). En segundo lugar, apuntó a la exhortación del paisaje tradicional como núcleo del orden social jerárquico y disciplinado que había originado la «chilenidad». Y tercero, reforzó los imperativos de la DSN sobre el paisaje como proyección de un Estado vivo, enérgico y territorialmente insatisfecho.

Entre otros dispositivos, las ilustraciones de la ENGM pusieron a circular dichas interpretaciones como si fueran conocimientos probados, convirtiendo en contenido divulgativo tanto sus metáforas sentimentales como su credo geográfico politizado. Su retórica gráfica cobró capacidad persuasiva en el seno del proyecto comunicacional, cultural y educacional autoritario, promotor de los clichés tradicionales y nacionalistas. De hecho, si el <paisaje tradicional〉 ya era un patrimonio cultural de las derechas, fue la política cultural de la dictadura la que lo consolidó como patrimonio político. Más todavía, fue en ese contexto que el paisaje pudo exacerbarse como base del patriotismo y como elemento «naturalizador» de la población y del Estado.

De tal forma que las imágenes de la ENGM fueron motor y depósito de un sutil discurso geográfico-ideológico destinado a poblar la imaginación escolar y ciudadana, con lo cual empuñaron el paisaje chileno como «causa` política y como saber. 


\section{REFERENCIAS}

Ankersmit, F.R. Aesthetic politics: political philosophy beyond fact and value. StanfordCalifornia: Stanford University Press, 1996. Medio impreso.

Apey, María Angélica y Adolfo Ibáñez Santa María. Las nuevas regiones de Chile. Santiago: Editora Nacional Gabriela Mistral, 1975, tomos 1 y 2. Medio impreso.

Boisier, Sergio. "Chile: la vocación regionalista del gobierno militar». Eure 26:77 (mayo 2000). 81-107. Medio impreso.

Castillo, Eduardo. Puño y Letra, Movimiento social y comunicación gráfica en Chile. Santiago: Ocho Libros Editores, 2006. Medio impreso.

CEMA Chile. Galería artesanal. Santiago: Editora Nacional Gabriela Mistral, 1975. Medio impreso.

Cleary, Patricio. "Como nació la pintura mural política en Chile». Araucaria de Chile 42 (1988). 193-195. Medio impreso.

Cox, Ricardo y otros. Pensamiento Nacionalista. Santiago: Editora Nacional Gabriela Mistral, 1974. Medio impreso.

Cristi, Renato y Carlos Ruiz. El pensamiento conservador en Chile. Santiago: Editorial Universitaria, 1992. Medio impreso.

D’Albuquerque, Lucía e Irene Rostagno. Perfiles de un Chile joven. Santiago, Editora Nacional Gabriela Mistral, 1974. Medio impreso.

Donoso, Karen. La batalla del folklore. Los conflictos por la representación de la cultura popular chilena en el siglo XIX. Tesis de Licenciatura en Historia. Universidad de Santiago de Chile, 2008. Medio impreso.

Errázuriz, L.H. «Dictadura militar en Chile. Antecedentes del golpe estético-cultural». Latin American Research Review 2 (2009). 136-157. Medio impreso.

Eyzaguirre, Jaime. Breve historia de las fronteras de Chile. Santiago: Editorial Universitaria, 1974. Medio impreso.

Folch-Serra, Mireia. «El paisaje como metáfora visual: cultura e identidad en la nación posmoderna». La construcción social del paisaje. Ed. Juan Nogué. Madrid: Ed. Biblioteca Nueva, 2007. 137-159. Medio impreso.

Foucault, Michel. Arqueología del saber. Buenos Aires: Siglo XXI Editores, 2005. Medio impreso.

Gobierno de Chile. Declaración de Principios. Santiago: DINACOS, Impresos Esparza y Cía Ltda, 1974. Medio impreso.

- Política cultural del Gobierno de Chile. Santiago: La Asesoría, 1974. Medio impreso.

- Chile. 11 de septiembre de 1975. Santiago: Editora Nacional Gabriela Mistral, 1975. Medio impreso.

. Objetivo Nacional de Chile: diciembre 1975. Santiago: Impresora Filadelfia, 1975. Medio impreso.

González Videla, Gabriel. Memorias. Santiago: Editora Nacional Gabriela Mistral, 1975. Medio impreso.

Grosse, Juan. Visión de Aisén: expediciones del explorador don Juan Augusto Grosse I. Santiago: s.n., 1974. Medio impreso. 
Gutiérrez, Rodrigo. Monumento conmemorativo y espacio público en Iberoamérica. Madrid: Ediciones Cátedra, 2004. Medio impreso.

Guzmán, Daniela. La cueca urbana. Antecedentes históricos y sociales de una danza de tradición popular. Memoria de Título. Universidad de Chile, 2007. Medio impreso.

Hobsbawm, Eric y Terence Ranger. La invención de la tradición. Barcelona: Editorial Crítica, 2002. Medio impreso.

Instituto de Estudios Generales. Los pioneros. Santiago: Editora Nacional Gabriela Mistral, 1974. Medio impreso.

Instituto Geográfico Militar. Atlas Geográfico de Chile: para la educación. Santiago: Instituto Geográfico Militar, 1985. Medio impreso.

Jarpa, Sergio. Creo en Chile. Santiago: Sociedad Impresora Chile, 1973. Medio impreso.

Kay, Ronald. Del espacio de acá: señales para una mirada americana. Santiago: Editores Asociados, 1980. Medio impreso.

León, René. Diversiones y juegos populares chilenos. Santiago: Editora Nacional Gabriela Mistral, 1974. Medio impreso.

Lotman, Iuri M., "Acerca de la semiosfera». La Semiosfera I. Semiótica de la cultura y del texto. Madrid: Cátedra, 1996. Medio impreso.

Maldonado, Carlos, Sergio González y Sandra McGee, «Ligas Patrióticas: un caso de nacionalismo, xenofobia y lucha social en Chile». Revista de Investigaciones cientificas y tecnológicas 1:1 (1993). 37-49. Medio impreso.

McGee, Sandra. Las Derechas: The Extreme Right in Argentina, Brazil and Chile, 1890-1939. Stanford: Stanford University Press, 1999. Medio impreso.

Mizón, Luis. Claudio Gay y la identidad cultural chilena. Santiago: Editorial Universitaria, 2001. Medio impreso.

Morand, Carlos. Llegarán de noche. Santiago: Editora Nacional Gabriela Mistral, 1976. Medio impreso.

Muzzopappa, María Eva, «El soldado perfecto. La chilenidad en el discurso del Ejército". Identidad y Nación en América Latina. Eds. María Eva Muzzopappa y otros. Santiago: Ediciones de la Facultad de Filosofía y Humanidades-Lom, 2004. 239-255. Medio impreso.

Nordenflycht, José. «Territorio, filiación y texto: de la historia del arte en Chile a la historia del arte chileno". Iconografía, identidad y cambio de siglo (XIX-XX): Jornadas de Historia del Arte en Chile. Comps. Fernando Guzmán y otros. Santiago: RIL, 2003. 31-40. Medio impreso.

O’Gorman, Edmundo. La invención de América: investigación acerca de la estructura histórica del Nuevo Mundo y del sentido de su devenir. México D.F.: Fondo de Cultura Económica, 2003. Medio impreso.

Orrego, Francisco. El Océano Pacífico. Santiago: Editora Nacional Gabriela Mistral, 1975. Medio impreso.

Pinochet, Augusto. Geopolítica. Santiago: Editorial Andrés Bello, 1984. Medio impreso.

Pinto, Julio y Verónica Ortiz de Zárate. ¿Chilenos todos? La construcción social de la nación (1810-1840). Santiago: Lom ediciones, 2009. Medio impreso.

Rodríguez-Plaza, Patricio. "La visualidad urbana en el Chile de la Unidad Popular». Cartel Chileno, 1963-1973. Comp. Eduardo Castillo. Santiago: Ediciones B, 2004. Medio impreso. 
Silva, Bárbara. Identidad y nación entre dos siglos. Patria Vieja, Centenario y Bicentenario. Santiago: Lom Ediciones, 2008. Medio impreso.

Soublette, Gastón. La Estrella de Chile. Valparaíso: Ediciones Universitarias de Valparaíso, 1984. Medio impreso.

Urquijo, Pedro S. y Narciso Barrera. "Historia y paisaje. Explorando un concepto geográfico monista». Andamios. Revista de Investigación Social 5 (2009). 227-252. Revista electrónica. Fecha de ingreso: 8 de noviembre de 2010.

Valdivia, Verónica. El golpe después del golpe. Leigh vs. Pinochet. Chile, 1960-1980. Santiago: Lom Ediciones, 2003. Medio impreso.

. Nacionales y gremialistas. El «parto» de la nueva derecha política chilena, 19641973. Santiago: Lom ediciones, 2008. Medio impreso.

«Versos de Camilo Henríquez celebrando haberse enarbolado en la Plaza Mayor de Santiago el estandarte nacional». El Monitor Araucano, Tomo I. N 31. Jueves, 17 de junio de 1813. Fuentes documentales y bibliográficas para el estudio de la historia de Chile. Universidad de Chile. Sitio web. Fecha de ingreso: 2 de enero de 2011.

Vico, Mauricio y Mario Oses. Un grito en la pared. Psicodelia, compromiso político y exilio en el cartel chileno. Santiago: Ocho libros, 2009. Medio impreso.

Voionmaa Tanner, Liisa, "Construcción simbólica de la nación chilena vista desde la iconografía. Una propuesta comparativa». Iconografía, identidad y cambio de siglo (XIX-XX): Jornadas de Historia del Arte en Chile. Comps. Fernando Guzmán y otros. Santiago, RIL, 2003. 121-138. Medio impreso.

Recepción: 25 de abril de 2011 Aceptación: 11 de octubre de 2011 